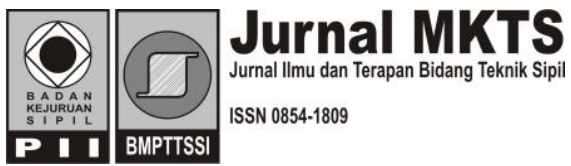

\title{
Assessment of Lean Construction Principles: A Case Study at Semarang Medical Centre Hospital Project
}

\author{
Matias Roy Adi Wijaya \\ Jurusan Teknik Sipil, Fakultas Teknik, Universitas Diponegoro \\ Jl.Prof. Soedarto, SH, Tembalang, Semarang 50275 \\ E-mail: matiasroy@gmail.com \\ Jati Utomo Dwi Hatmoko \\ Jurusan Teknik Sipil, Fakultas Teknik, Universitas Diponegoro \\ Jl.Prof. Soedarto, SH, Tembalang, Semarang 50275 \\ E-mail: jati.hatmoko@gmail.com \\ Suripin \\ Jurusan Teknik Sipil, Fakultas Teknik, Universitas Diponegoro \\ Jl.Prof. Soedarto, SH, Tembalang, Semarang 50275 \\ E-mail: suripin.ar@gmail.com
}

\begin{abstract}
The lean construction frameworks have been developed for years to enhance the poor performance of Indonesian project delivery system which influenced by the waste of non-value adding activities. Never the less most of the developments were limited on working process and lack in people empowerment. Toyota Way which integrate working process optimization and people empowerment, was developed as a lean construction frame works. This paper aimed to assess the implementation of Toyota Way principles in project delivery system by observing project's delivery current state (status quo). The assessment began by conducting a questionnaire survey about Toyota Way implementation which then validated by interview with involved stakeholders and field observation. The assessment showed that project's stakeholders were still unfamiliar with Toyota Way concept. Although some Toyota Way guidelines have been used in projects completion process such as visual management and training program, it found that those guidelines had not fully implemented. The project delivery system was lack of process focus and concerns more on relationship inter-parties. It also found thatToyota Way implementation will constrained by the difficulties to change the status quo of project delivery. Moreover, it seems that construction projects need practical guidelines to simplify the Toyota Way implementation in project delivery system such as project flow evaluation and system of reflection.
\end{abstract}

Keywords: Toyota way, Lean construction, Project delivery system, Status quo assessment, Non value adding activities.

\begin{abstract}
Abstrak
Kerangka kerja lean construction dikembangkan untuk meningkatkan perfoma buruk dari penyelesaian proyek konstruksi di Indonesia. Namun demikian, pengembangan yang dilakukan masih terbatas pada proses kerja dan belum adanya pelibatan sumber daya manusia. Konsep Toyota Way yang mengintegrasikan proses kerja dan pelibatan sumberdaya manusia, dikembangkan sebagai salah satu kerangka kerja pada lean construction. Penelitian ini bertujuan untuk mengkaji penerapan prinsip-prinsip Toyota Way pada penyelenggaraan proyek konstruksi, dengan mengkaji sistem pelaksanaan proyek yang ada. Penelitian diawali dengan pengisian kuisioner mengenai penerapan Toyota Way untuk pihak-pihak yang terlibat pada penyelesaian proyek, yang kemudian divalidasi dengan wawancara serta observasi lapangan. Hasil kajian menunjukkan responden kurang mengenal konsep Toyota Way. Beberapa panduan penerapan Toyota Way telah dilakukan pada penyelesaian proyek seperti manajemen visual dan pelatihan pekerja, namun demikian
\end{abstract}


penerapannya masih dirasa belum secara utuh. Lebih lanjut, hasil kajian juga menunjukkan sistem penyelenggaraan proyek kurang berfokus pada proses kerja dan lebih berfokus untuk menjaga hubungan baik antar pihak. Penerapan Toyota Way juga mendapat hambatan sulitnya mengubah kondisi eksisting dari sistem penyelenggaraan proyek. Lebih lanjut, beberapa panduan praktis penerapan Toyota Way diperlukan untuk memudahkan penerapan Toyota Way pada proyek konstruksi antara lain evaluasi waste pada alur kerja dan sistem refleksi akan hasil kerja.

Kata-kata Kunci: Toyota way, Lean construction, Sistem penyelenggaraan proyek, Kajian status quo, kegiatan tidak bernilai tambah.

\section{Introduction}

The growth of Indonesian economic is now running slowly. One reason for this economics decline is the decreasing performance of Indonesian projects delivery (Bank Indonesia, 2014). Moreover, Indonesian construction project's productivity and quality are low (Willar, 2010). This poor performance of construction projects performance was affected by the waste of non-value adding activities on projects life cycle (Alwi, 2002). Waste that are common to see in Indonesian construction projects, i.e. waiting, projects delay, changeorders, overstocking inventories, and projects site untidiness (Hadiman et al., 2014). This type of waste are affecting the project's completion process and productivity, and was caused by the low commitment on quality of construction project's stakeholder pertaining with construction delivery process (Soekiman et al., 2011; Larasati and Watanabe, 2009).

It also stated that construction project completion in Indonesia is still suffered from conflict/disputes among involved parties because of poor coordination system. Moreover, in Indonesian construction projects, only $75 \%$ of working time is value adding activities, human resources empowerment only $67 \%$, and project completion percentage only $87 \%$ from all projects activities (Larasati and Watanabe, 2009; Alwi, 2013). In addition, waste of non-value adding activities are still considered as common things for most of construction project's stakeholder and were not need to have any root-cause solution (Andi et al., 2005).
One developed solution for those problems is Lean Construction. As a working concept, lean construction aims to eliminate waste of non-value adding activities while focusing on customer's value generation. Lean construction was developed from lean production system on manufactur, Toyota. The conservative view of production system divides macro production system into smaller sub process of input-output convertion, in which arising the waste of non-value adding activities. New production concept has been developed that viewing production process as conversion and flow process (Figure 1), which aims to eliminating non-value adding activities in flow process and focusing on value generation for customer in conversion process.

For years, development of lean construction resulting in lean construction frameworks and its implementation guidelines. However, most of lean concept development werebased on lean thinking concept by Womack and Jones (1996). Lean thinking comprises 5 principles consist of defining value for customer, creating value stream, steady flow system, pull system, and perfection. Nevertheless, some arguments to lean thinking are focused only on working process, exploitative into human resources and lack of human resources skill improvement and people empowerment (Gao and Low, 2014). Lean thinking concept assessed to be unsuitable to be implemented in construction sector (Winch, 2006). Some lean construction tools have been successfully implemented on project delivery process such as $5 \mathrm{~S}$ to maintain workplace tidiness, visual management to achieve better working condition through visual signs. However, it was limited only on process focus tools. The project delivery system is still lacking in human resources empowerment.

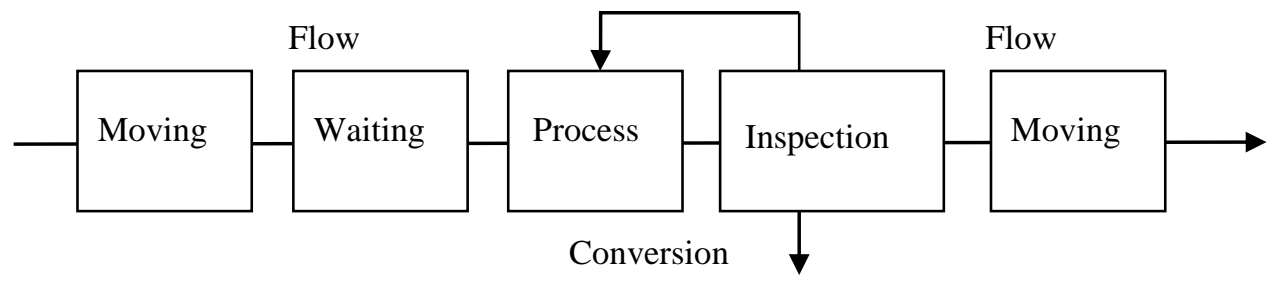

Figure 1. Conversion and flow (Koskela, 2002) 
Recent studies on lean construction framework developments were on Toyota Way as lean construction philosophy. Toyota Way was developed as working philosophy in manufacturing and was later developed and adopted in construction sector (Gao, 2013). Toyota Way concerns on process optimization and human resources empowerment. Toyota Way comprises 14 basic principles divided into 4 models, which are philosophy model, process model, people and partner model, and problem-solving model. Toyota Way principles integrate "hard factor" or working process and "soft factor" or human resources empowerment. Toyota Way is in accordance with the concept that stated lean construction should be established with integration between these two major factor of project delivery system.

In order to assess Toyota Way implementation on construction project delivery system, a case study research has been made to assess the extent of Toyota Way implementation by observing the project's status quo of the project delivery process. The first stage was conducted by developing a questionnaire about Toyota Way implementation guidelines and assessment on lean construction implementation. The quantitative used to observing the implementation level of Toyota Way guidelines on a real-life construction project. Then, qualitative method used to validate the result by doing interview and project site observation in order to achieve a better level of understanding on how Toyota Way guidelines have been implemented in the case-study project. It then followed by the review the hindrance on Toyota Way implementation at the construction project. Following these, an assessment was made about the extent of project delivery system on case study project. Finally, a discussion on practical Toyota Way guidelines were held to improve the project delivery performance.

\section{Lean construction toyota way}

Basically, lean construction is a working philosophy to generating a steady flow system that focusing on identification and elimination waste of non-value adding activities in construction supply chain (Ogunbiyi, 2014). Lean construction is an attempt to implement lean concept into construction sector. Lean implementation on construction sector became crucial because of nonvalue adding activities in construction that leads into waste, which attain $55-65 \%$ of total activities in construction process. While only $5-10 \%$ of activities are value adding activities (Diekmann et al., 2004).

Many research has been conducted this far todeveloplean construction frameworks in attempt to implement lean concept into construction sector. Most of lean construction framework developments was based on the Lean Thinking concept which relatively only focused on value generation and enhance working process value stream (Ogunbiyi, 2014; Picci and Graja, 2004, Eriksson, 2010). One of the lean construction framework development is observed by Gao (2013) which try to track back lean framework development with basic concept of Toyota lean production named Toyota Way. Toyota consists of 14 principles that can be divided into 4 models (Figure 2).

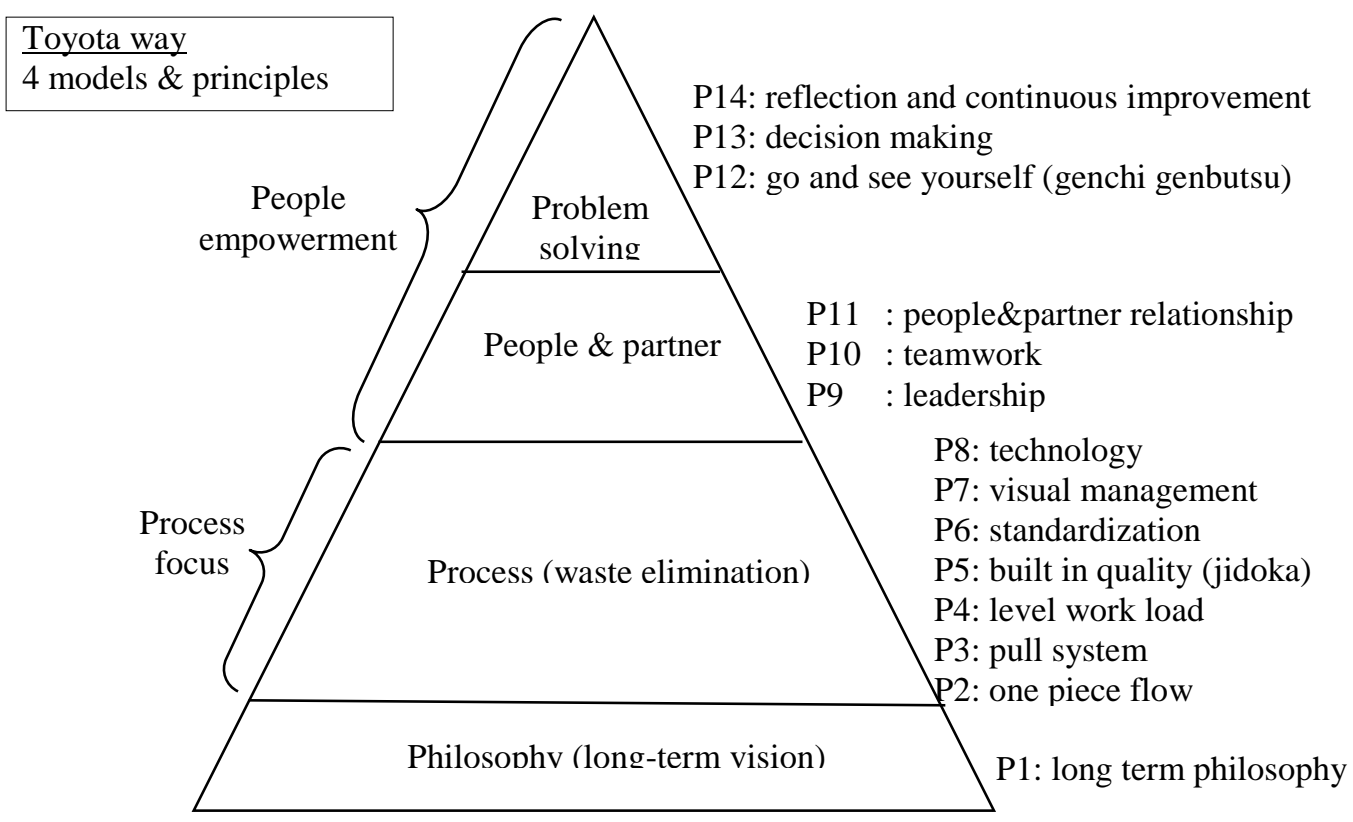

Figure 2. Toyota way models and principles (after gao and low, 2014) 


\begin{tabular}{|c|c|c|c|}
\hline \multicolumn{3}{|c|}{ Toyota way principles } & \multirow{3}{*}{$\begin{array}{c}\text { Lean thinking } \\
\text { by Womack \& Jones }\end{array}$} \\
\hline $\mathrm{P} 1$ & Long term philosophy & P8 Reliable technology & \\
\hline $\mathrm{P} 2$ & One piece flow & P9 Leadership & \\
\hline P3 & Pull system & P10 People and teamwork & \\
\hline P4 & Level out workload & P11 Respect partners & - Defining value from customer \\
\hline P5 & Built in quality & P12 Go and see yourself & - Clear value stream \\
\hline P6 & Standardization & P13 Decision consensus & - Continuous flow \\
\hline P7 & Visual control & $\begin{array}{l}\text { P14 Kaizen and continuous } \\
\text { improvment }\end{array}$ & - Pull system \\
\hline
\end{tabular}

Figure 3. Toyota Way concept and Lean Thinking concept

This Toyota Way concept model integrate the process focus and people empowerment system. With philosophy as a base point for this concept, process focus and people empowerment are built. Philosophy model is a long-term vision that could be the hardest factor for Toyota Way implementation. Implementing a long-term philosophy is about changing the status quo of the project delivery system. This could be achieved by focus on working process to eliminating waste and creating steady flow system, which supported by human resources empowerment on respecting others involved parties, challenging and developing working partners, growing leadership passion, and creating better coordination system in a teamwork. The succeed of lean implementation also supported by a good problem-solving method as a learning process, which achieved by system of reflection and continuous attempts of improvement.

In contrasting with lean thinking concept, Figure 3 briefly compare the principles of Toyota Way and Lean thinking. It is clear that Toyota Way principles are much beyond the principles of Lean Thinking, in which Toyota Way comprise both process focus and human resources empowerment while Lean thinking concept only focused on working process.

\section{Toyota way implementation assessment}

Green and May (2005) observed about the extent of lean concept implementation by observing current condition of construction projects delivery system and stated that there are 3 basic types of projects delivery system. The first is the model of waste elimination. In this model, the projects only view the delivery system only as process focused activities with aims to reducing waste of non-value adding activities. Lean principles that used on this type of projects are principles that more practical and process focus, such as $5 \mathrm{~S}$ system, visual management, and Just in time.

The second model is model of Partnering. This model have more focus on maintaining a good relationship among involved parties in the projects supply chain by enhancing a good relationship. A good relationship arises from better coordination system affected on project delivery. This second model is sought to eliminate disputes inter parties, especially from owner into main contractor. This second model mostly speak about system sharing, knowledge sharing, and trusting inter parties. Lean principles that used in this type of projects such as long-term contract, workshop, workers training program, and facilitator.

The last model and also the most sophisticated model is the Lean construction model. This model emphasized on integration between waste elimination and maintaining good relationship inter parties. This model attempts to implementing lean construction concept with changing the status quo of project delivery system. This model also emphasized on individual role in achieving good project delivery system with having a responsibility and commitment on working process, reflection on what have been done, and continuous improvement to attain better level of project delivery. The principles used in this model such as the using of reliable technology, prefabrication system, consideration of constructibility and buildability design system, and bottom-up system activities related to problemsolving activities and feedbacks from workers.

In order to adjusting the guidelines of lean implementation assessment, a lean construction guidelines compliance was made. The lean assessment guidelines were compile with the Toyota Way implementation guidelines (Table 1), based on Gao (2013). 
Table 1. Lean classification with toyota way guidelines

\begin{tabular}{|c|c|}
\hline Lean classification green-may & Toyota way implementation guidelines \\
\hline \multicolumn{2}{|r|}{ Model 1: Waste elimination } \\
\hline $\begin{array}{l}\text { - Waste elimination is paramount } \\
\text { - Focus on technical problems } \\
\text { - Aims to one piece flow } \\
\text { - Reducing variance } \\
\text { - Limited on working process }\end{array}$ & $\begin{array}{l}\text { - Establishing one piece flow with waste elimination on working } \\
\text { process } \\
\text { - Just in time in material supply } \\
\text { - Site layout adjustment } \\
\text { - Pull System } \\
\text { - Zero inventory level } \\
\text { - Kanban Tools } \\
\text { - Quality control } \\
\text { - Reducing variability with establishingstandard operating procedure } \\
\text { - Safety signas visual management }\end{array}$ \\
\hline \multicolumn{2}{|r|}{ Model 2: Partnering model } \\
\hline $\begin{array}{l}\text { - Focusing on long term } \\
\text { relationship } \\
\text { - Reducing disputes } \\
\text { - Collaboration system } \\
\text { - Sharing information and } \\
\text { experience } \\
\text { - Teamwork }\end{array}$ & $\begin{array}{l}\text { - Establishing one piece flow by focusing on long term relationship } \\
\text { inter-parties. } \\
\text { - Fullfil customer requirements } \\
\text { - Level out the workload } \\
\text { - Work } \\
\text { - Reducing conflict/disputes } \\
\text { - Information sharing } \\
\text { - Leaders support system } \\
\text { - Working with limited partners } \\
\text { - Decision making considering other involved parties }\end{array}$ \\
\hline \multicolumn{2}{|r|}{ Model 3: Lean construction } \\
\hline $\begin{array}{l}\text { - Focusing on changing the status } \\
\text { quo } \\
\text { - Structural change way of } \\
\text { thinking in design and working } \\
\text { process } \\
\text { - Using reliable integrated } \\
\text { technology } \\
\text { - Worker training program } \\
\text { - Reflection and continuous } \\
\text { improvement }\end{array}$ & $\begin{array}{l}\text { - Having long term vision } \\
\text { - Workers awareness on defect-reworks } \\
\text { - Responsibility on quality } \\
\text { - Cross trained member } \\
\text { - Technology to simplify process } \\
\text { - Well knowledged leader } \\
\text { - Root cause evaluation } \\
\text { - Second opinion consideration } \\
\text { - Reflection and continuous improvement }\end{array}$ \\
\hline
\end{tabular}

\section{Research Method}

The method used in this research is combination case-study conducted by integrating quantitative and qualitative methods. In order to assess Toyota Way implementation on construction delivery system, a current condition (status quo) reviewof the project's delivery process has been made. The respondents used in this research were chosen by purposive snowball sampling method, and involving inter-parties of projects stakeholder (owner, project management, and main contractor) in order to find broader information of project's stakeholders interaction in project delivery process. This research was conducted in the Semarang Medical Centre project development. This single research object choosen because of its complexity, multi-years projects, invloving national and international stakeholders, and has to deal with some obstacles to performing this mega project construction process among densely populated residential, and right beside this existing building.

The first stage of this research was developing a questionnaire about Toyota Way implementation guidelines and assessment on lean construction implementation. The quantitative used to observing the implementation level of Toyota Way guidelines on a real-life construction project. Then, qualitative method used to validate the result by doing some interview and project site observation in order to achieve a better level of understanding on how Toyota Way guidelines have been implemented in the case-study project. The complete of this research phase are presented in Table 2 as below. 
Matias Roy Adi Wijaya, Jati Utomo Dwi Hatmoko, Suripin

Assessment of Lean Construction Principles: A Case Study at Semarang Medical Centre Hospital Project

Table 2. Research phase

\begin{tabular}{lcc}
\hline \multicolumn{1}{c}{ Reseach purpose } & Process & Qualitative/quantitative \\
\hline $\begin{array}{l}\text { Identification lean construction principles with Toyota Way } \\
\text { principles }\end{array}$ & $\begin{array}{c}\text { Preliminary } \\
\text { Survey }\end{array}$ & $\begin{array}{c}\text { Qualitative, } \\
\text { Literature Review }\end{array}$ \\
\hline Develop a lean classification system based on literature review & $\begin{array}{c}\text { Qualitative, } \\
\text { Literature Review }\end{array}$ \\
\hline $\begin{array}{l}\text { Observing the extent of Toyota Way principles implemented in } \\
\text { project delivery system }\end{array}$ & Phase 2 & $\begin{array}{c}\text { Quantitative, } \\
\text { Qualitative }\end{array}$ \\
\hline Comparing research result with literature review & Discussion & $\begin{array}{c}\text { Compile of } \\
\text { Previous findings }\end{array}$ \\
\hline
\end{tabular}

The questionnaire used in this research is adapted from the questionnaire developed by Gao (2013). The questionnaire consisted of 14 major question of Toyota Way principles and divided into some specific sub-question about those principles implementation guidelines. the questionnaire using 5 point Likert Skale importance-performance. The average result of this questionnaire then plotted into matrix of importance-performance.

\section{Data analysis and Disscussions}

The questionnaire resulted means of Toyota Way performance and importance principles. The result (table3) showed that all Toyota Way principles has been moderatelty implemented in project delivery process, which showed high rating point (between 3,75-4,4 Likert Skale). Along with this, the importance factor also gota good result with high rating point (above 4 Likert Skale). The result then plotted into importance-performance matrix which shown in Figure 4.

Table 3. Questionnaire mean results

\begin{tabular}{llcc}
\hline \multirow{2}{*}{ No } & \multicolumn{1}{c}{ Toyota way principles } & \multicolumn{2}{c}{ Mean } \\
\cline { 3 - 4 } & & Implementation & Importance \\
\hline P1 & Long term philosophy & 4.29 & 4.62 \\
P2 & One piece flow & 3.90 & 4.71 \\
P3 & Pull system & 3.81 & 4.69 \\
P4 & Level out the workload & 4.02 & 4.60 \\
P5 & Built in quality & 3.83 & 4.67 \\
P6 & Standardized work & 3.88 & 4.43 \\
P7 & Visual control & 3.93 & 4.64 \\
P8 & Reliable technology & 4.43 & 4.25 \\
P9 & Leadership & 4.24 & 4.64 \\
P10 & Teamwork & 4.21 & 4.52 \\
P11 & Respect partners & 4.38 & 4.52 \\
P12 & Go and see yourself & 4.10 & 4.57 \\
P13 & Decision making & 3.98 & 4.31 \\
P14 & Reflection and continuous improvement & & 4.60 \\
\hline
\end{tabular}

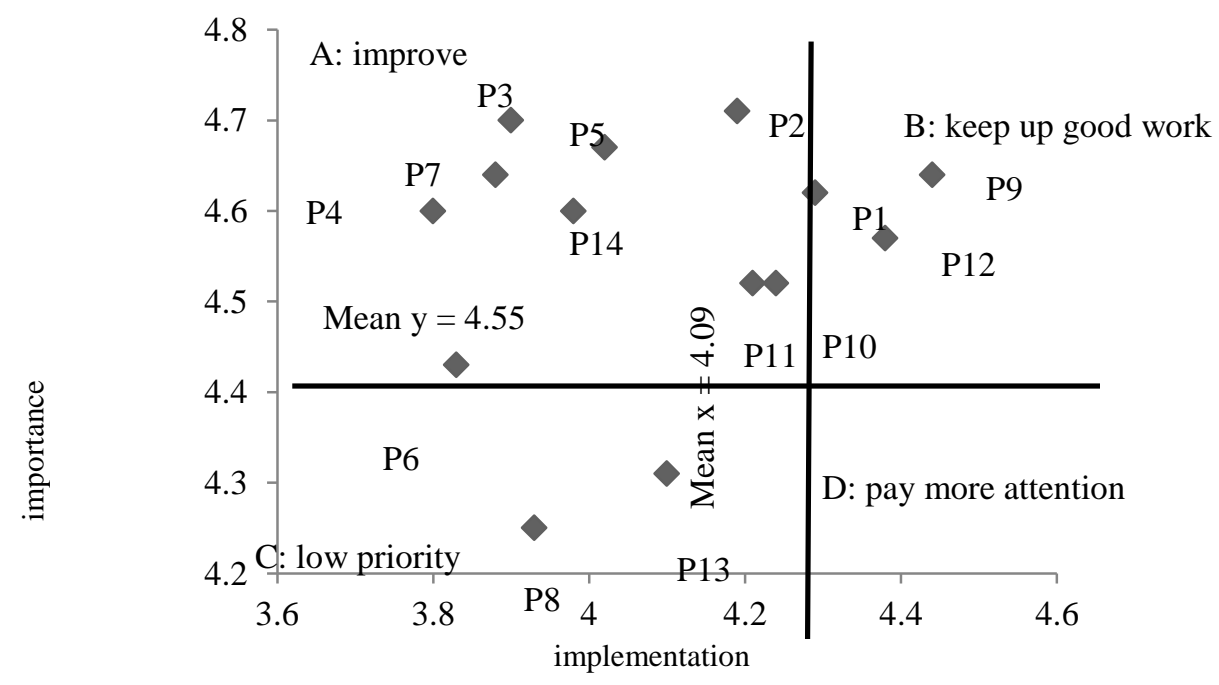

Figure 4. Toyota Way concept and Lean Thinking concept 
Figure 4 clearly shows that all Toyota Way principles are plotted in the range of 3-4 Likert Skale point. From this result, it could concluded that at case-study projects delivery system, Toyota Way principles has been moderately implemented and almost all of those principles are considers to be important enough in delivery system.

\section{Hindrance in Toyota Way Implementation}

As the questionnaire result, the biggest hindrance of Toyota Way implementation is financial constrain. As at most of respondent stated that they have to allocating extra funding related to worker training program and also providing safety tools and other visual management tools.

Table 4. Hindrance in toyota way implementation

\begin{tabular}{lc}
\hline \multicolumn{1}{c}{ Hindrance } & Mean \\
\hline Have no working philosophy & 2,929 \\
Unfamiliar with lean concept & 2,857 \\
Financial factor & 3,571 \\
Lack of worker empowerment & 2,857 \\
Lack of management supports & 2,714 \\
Too much working partners & 3,000 \\
Unfair Competition inter-parties & 2,571 \\
Unable to make decision while needed & 3,357 \\
\hline
\end{tabular}

Moreover, as some respondens said that Toyota Way implementation would also facing the hindrance to change the project delivery system's status quo. As the difficulties to chage working culture that has been implemented at construction delivery process for years.

\section{The Findings}

In short, from the interview with project's stakeholders resulted that Toyota Way have not been fully implemented in project delivery process. The respondent stated the terms "lean construction" was a new things, although some respondent said the terms "Toyota Way" is more familiar. From the interview, we found that the respondent mostly unfamiliar with Toyota Way principles but still familiar for some Toyota Way implementation guidelines such as Just in Time, Huddle Meeting, and Visual System. Eventhough there were only small number of respondent that stated they were familiar or ever heard about Toyota Way principles in manufacturing sector, but never knowing Toyota Way principles have been adopted for construction project.

From the interview and the project site observation, resulted some findings that its not in accordance with the questionnaire finding. From the interview, resulted that Toyota Way principles implementation on the project site was not fully implemented. Project site still constrained with some basic problems in construction, such as waiting, delay, defect-rework, and disputes interparties. The research findings are described on Table 5 as follow.

From the interview findings, Toyota Way principles are not fully implemented in project delivery system. Moreover, those results are not in accordance with the questionnaire result, and it could be concluded that this study-case site project was not familiar with the Toyota Way concept. The questionnaire reflects the project's stakeholder understanding on viewing their own delivery system. It could be concluded that the project's stakeholders views the project delivery system was pretty good reflected by high level of Likert Point on all Toyota Way principles. Nevertheless, from interview and site observation it found that project delivery system was not fully implemented Toyota Way principles. There are still discrepancy on Toyota Way implementation guidelines on this project's delivery sistem.

\section{Toyota Way implementation assessment (Toyota Way classification system)}

To assess the extent of Toyota Way implementation on construction project, an assessment system has been made based on assessment system by Green and May (2005) that divided project delivery system into 3 different models as stated in previous section of this paper. The Toyota Way implementation guidelines were compile with exsisting guidelines from Green and May to adjust with these research scope. The result was presented on Table 1 .

The assessment on the extent of lean implementation was found by observing the current state of project delivery performance. The concept was to found the greater match of implementation guidelines on each models with the project current state. The assessment used the findings from previous interview and site observation on how Toyota Way has been implemented in construction project. The result of this assessment in short, showed that the casestudy project have more focus on maintaining a good relationship inter-parties. However this projects assessed to be lack of focus on waste elimination at working process. This projects also still far away to attaining the the model of truly lean construction. The complete assessment system was describe in Table 6. 
Matias Roy Adi Wijaya, Jati Utomo Dwi Hatmoko, Suripin

Assessment of Lean Construction Principles: A Case Study at Semarang Medical Centre Hospital Project

Table 5. Research findings

\begin{tabular}{|c|c|c|}
\hline \multicolumn{2}{|c|}{ Toyota way principles } & Research findings \\
\hline $\mathrm{P} 1$ & $\begin{array}{l}\text { Long term } \\
\text { philosophy }\end{array}$ & $\begin{array}{l}\text { - Project management knowing the philosophy to delivering the project in the right quality, } \\
\text { budget, and time } \\
\text { - Low level of workers still have not familiar with this philosophy, and tends to performs their job } \\
\text { to meet the daily work target and not too consider on its results. } \\
\text { - Sometimes change orders given but were not in accordance with the projects completion } \\
\text { progress. }\end{array}$ \\
\hline P3 & Pull system & $\begin{array}{l}\text { - Inventory control with manual system } \\
\text { - Low respect to do the working process accordance with standard operating procedure } \\
\text { - Could not implement zero inventory concept for safety reason }\end{array}$ \\
\hline $\mathrm{P} 4$ & $\begin{array}{l}\text { Level out the } \\
\text { workload }\end{array}$ & $\begin{array}{l}\text { - There are coordination meeting to discuss about workload adjustment } \\
\text { - Delay in daily workload would overburden the next day daily workload } \\
\text { - The lack of human resources affecting ability to complete daily workload }\end{array}$ \\
\hline P6 & $\begin{array}{l}\text { Standardized } \\
\text { work }\end{array}$ & $\begin{array}{l}\text { - Attempt to reducing variability by standardized on used material } \\
\text { - Workers were not aware on standard operating procedure. } \\
\text { - Using only limited prefabricated material (piles and ready-mix concrete) } \\
\text { - Lack of workers empowerment to established working standard }\end{array}$ \\
\hline P7 & Visual control & $\begin{array}{l}\text { - Management supports on safety was good } \\
\text { - Low level workers were not aware on safety, including not aware of safety tools } \\
\text { - Lack of tidiness commitment on working site. }\end{array}$ \\
\hline P8 & $\begin{array}{c}\text { Reliable } \\
\text { technology }\end{array}$ & $\begin{array}{l}\text { - Utilization of technology, but limited only on simple, practical, and familiar technology to } \\
\text { support daily activities. }\end{array}$ \\
\hline P9 & Leadership & $\begin{array}{l}\text { - Management support system in projects completion } \\
\text { - Lack of workers empowerment in decision making system } \\
\text { - There were no system to grow leaders from workers }\end{array}$ \\
\hline $\mathrm{P} 10$ & Teamwork & $\begin{array}{l}\text { - Workers training programs are limited to some level of workers } \\
\text { - There were no cross trained member }\end{array}$ \\
\hline P11 & $\begin{array}{l}\text { Respect } \\
\text { partners }\end{array}$ & $\begin{array}{l}\text { - Establishing long term relationship inter-parties } \\
\text { - Understanding customers value } \\
\text { - Works with lots of partners, leads to difficulties in coordination inter-parties }\end{array}$ \\
\hline $\mathrm{P} 12$ & $\begin{array}{l}\text { Go and see } \\
\text { yourself }\end{array}$ & $\begin{array}{l}\text { - There were attempt to go and see problems in project site } \\
\text { - Observation that was held only limited on solving the arising problems } \\
\text { - Only little attempt to find and solve the root cause }\end{array}$ \\
\hline $\mathrm{P} 13$ & $\begin{array}{l}\text { Decision } \\
\text { making }\end{array}$ & $\begin{array}{l}\text { - Decision making system was based on consensus, but not always implemented due to limited } \\
\text { project completion time } \\
\text { - Decision making sometimes rely on the leader experience }\end{array}$ \\
\hline $\mathrm{P} 14$ & $\begin{array}{l}\text { Reflection and } \\
\text { continuous } \\
\text { improvement }\end{array}$ & $\begin{array}{l}\text { - Plan-Do-Check-Act System limited only as inspection of work outputs } \\
\text { - Lack of reflection and continuous improvement }\end{array}$ \\
\hline
\end{tabular}

\section{Conclusion}

Based on previous findings, it could be concluded as following:

1. Toyota Way concept are in accordance with concept of lean construction principles that integrating process focus and people empowerment.

2. As the result from survey, the Semarang Medical Centre's stakeholders are still unfamiliar with Toyota Way concept. It also found that implementation of Toyota Way principles in the project delivery system were not fully implemented.
3. The lean assessment resulted that Semarang Medical Centre Project's delivery system was lack of focus on working process, and have more focus on maintaining good relationship inter-parties. The Semarang Medical Centre Project's current state, more likely to be in Partnering models. To achieve steady flow, it is needed to adjust the working proces and maintain good relationship inter-parties.

With respect to project delivery process, its significant to change the conventional view that stated Toyota Way implementation will need extra funds and the hindrance to change the status quo of project delivery system. However, Toyota Way implementation should be implemented gradually with smaller group of training, and small efforts 
Table 6. Toyota way classification system

\begin{tabular}{|c|c|c|c|c|c|c|c|c|}
\hline \multicolumn{3}{|c|}{ Model 1 waste elimination } & \multicolumn{3}{|c|}{ Model 2 partnering } & \multicolumn{3}{|c|}{ Model 3 true lean construction } \\
\hline \multirow{2}{*}{$\begin{array}{c}\text { Classification guidelines } \\
\begin{array}{c}\text { Steady flow by focus on } \\
\text { waste elimination }\end{array} \\
\end{array}$} & \multicolumn{2}{|c|}{$\begin{array}{l}\text { Project current state of delivery } \\
\text { system }\end{array}$} & \multirow{2}{*}{\begin{tabular}{|c|} 
Classification guidelines \\
Maintaining good relationship
\end{tabular}} & \multicolumn{2}{|r|}{$\begin{array}{c}\text { Project current state of delivery } \\
\text { system }\end{array}$} & \multirow{2}{*}{$\begin{array}{c}\text { Classification guidelines } \\
\text { Living the long term } \\
\text { philosophy } \\
\end{array}$} & \multicolumn{2}{|r|}{$\begin{array}{c}\text { Project current state of } \\
\text { delivery system }\end{array}$} \\
\hline & $\mathrm{X}$ & Unaware of waste & & $\mathrm{V}$ & Establishing long term partners & & $\mathrm{V}$ & $\begin{array}{c}\text { Management long term } \\
\text { vision }\end{array}$ \\
\hline Just in time inventory & $\mathrm{X}$ & Not always just in time & $\begin{array}{l}\text { Conform the needs of customers } \\
\text { including change orders }\end{array}$ & $\mathrm{V}$ & Conforms the customer's needs & Stop fix the problems & $\mathrm{X}$ & Not extent \\
\hline Project layout adjustment & $\mathrm{V}$ & $\begin{array}{l}\text { Layout adjustment to eliminate } \\
\text { double handling }\end{array}$ & $\begin{array}{c}\text { Make sure all have been done before } \\
\text { starting new task }\end{array}$ & $\mathrm{X}$ & Not always done & $\begin{array}{c}\text { Responsibility on task to be } \\
\text { done }\end{array}$ & $\mathrm{X}$ & Observed in huddle meeting \\
\hline Pull system & $\mathrm{X}$ & $\begin{array}{c}\text { The distraction of project } \\
\text { delivery performance }\end{array}$ & Level the workload & $\mathrm{V}$ & Daily workload adjustment & Material prefabrication & $\mathrm{X}$ & $\begin{array}{c}\text { Just a little of prefab } \\
\text { materials }\end{array}$ \\
\hline Zero inventory level & $\mathrm{X}$ & $\begin{array}{c}\text { Not always impelemted due to } \\
\text { safety reason }\end{array}$ & $\begin{array}{l}\text { People empowerment in working } \\
\text { standard establishing }\end{array}$ & $\mathrm{X}$ & Not any & Reliable technology & $\mathrm{X}$ & Not always \\
\hline Kanban tools & $\mathrm{X}$ & Using manual system & Information sharing & $\mathrm{V}$ & $\begin{array}{c}\text { Information sharing by visual } \\
\text { system }\end{array}$ & $\begin{array}{c}\text { Practical technology to support } \\
\text { delivery system }\end{array}$ & $\mathrm{V}$ & $\begin{array}{l}\text { To support the delivery } \\
\text { process }\end{array}$ \\
\hline Daily workload completion & $\mathrm{X}$ & $\begin{array}{l}\text { Still constrained from delays } \\
\text { and impacted to project's } \\
\text { completion progress }\end{array}$ & Manajement support on safety & $\mathrm{V}$ & $\begin{array}{l}\text { Penalty system not } \\
\text { implementing safety }\end{array}$ & Deep knowledged leader & $\mathrm{X}$ & $\begin{array}{l}\text { Sometimes still lack of } \\
\text { knowledge }\end{array}$ \\
\hline Quality control & $\mathrm{V}$ & There is quality control system & Trainig system & $\mathrm{V}$ & $\begin{array}{l}\text { Training system only some } \\
\text { level of workers }\end{array}$ & Root cause analysis & $\mathrm{X}$ & Not always \\
\hline $\begin{array}{l}\text { Variance reduction by } \\
\text { establishing standard } \\
\text { operating procedure }\end{array}$ & $\mathrm{V}$ & $\begin{array}{l}\text { Some extent have been } \\
\text { implemented (standardized } \\
\text { materials), but stll lack } \\
\text { awareness of sop }\end{array}$ & Teamwork & $\mathrm{V}$ & $\begin{array}{l}\text { Sharing system on working } \\
\text { process }\end{array}$ & Cross trained member & $\mathrm{X}$ & Not ectent \\
\hline Safety signs & $\mathrm{V}$ & $\begin{array}{c}\text { Well established but lack of } \\
\text { impementation }\end{array}$ & Works with limited partners & $\mathrm{X}$ & Large supplier/partners & Go and see yourself & $\mathrm{V}$ & By field trip obsevation \\
\hline Project site tidiness & $\mathrm{X}$ & $\begin{array}{l}\text { Workers not aware on site } \\
\text { tidiness }\end{array}$ & Consensus decision making & $\mathrm{X}$ & Not always & Alternatives option & $\mathrm{V}$ & As a backup plan \\
\hline & & & $\begin{array}{c}\text { Communication system, knowledge } \\
\text { sharing }\end{array}$ & $\mathrm{V}$ & $\begin{array}{l}\text { Communication system by } \\
\text { coordination meeting }\end{array}$ & Reflection system & $\mathrm{X}$ & $\begin{array}{c}\text { Lack of system reflection, by } \\
\text { experienced bad vluent }\end{array}$ \\
\hline & & & & & & Plan-do-check-act & $\mathrm{X}$ & $\begin{array}{c}\text { Only on observing working } \\
\text { process }\end{array}$ \\
\hline \multicolumn{3}{|c|}{$\begin{array}{l}\text { Percentage } \\
36 \%\end{array}$} & \multicolumn{3}{|c|}{$\begin{array}{l}\text { Percentage } \\
65 \%\end{array}$} & \multicolumn{3}{|c|}{$\begin{array}{l}\text { Percentage } \\
\quad 38,5 \%\end{array}$} \\
\hline
\end{tabular}


such as establishing leadership system and growing responsibility from workers. It also needed to enhance the working completion system by following the established standard operating system. It needs to observing the waste of nonvalue adding activities on project delivery system and also system of reflection and continuous improvement.

\section{References}

Alwi, S., 2013. Factors Influencing Construction Productivity In The Indonesian Context. Proceedings of the Eastern Asia Society for Transportation Studies, Vol.4.

Alwi, S., Hampson, K., dan Mohamed, S., 2002. Non Value-Adding Activities: A Comparative Study of Indonesian and Australian Construction Projects. Proceedings of the 10th annual conference of the IGLC. Gramado, Brazil.

Andi, Winata, S., dan Hendarlim, Y., 2005. Faktor-faktor Penyebab Rework pada Pekerjaan Konstruksi, Civil Engineering Dimension Vol.7 No.1.

Bank Indonesia, 2014. Laporan Nusantara: Kajian Ekonomi dan Keuangan Regional, Bank Indonesia Departemen Kebijakan Ekonomi dan Moneter, Jakarta.

Diekmann, J. E., 2004. Application of lean manufacturing principles to construction. Construction Industry Institute.

Egan, J., 1998. Rethinking Construction: Report of the Construction Task Force, HMSO.http://constructingexcellence.org.uk/wpco ntent/uploads/2014/10/rethinking_construction_re port.pdf, London.

Eriksson, P. E., 2010. Improving Construction Supply Chain Collaboration and Performance: a Lean Construction Pilot Project, Supply Chain Management - An International Journal.

Gao, S., 2013. The Toyota Way Model: An implementation Framework on Large Chinese Construction Firm, National University of Singapore.

Gao, S., dan Low, S. P, 2014. Lean Construction Management: The Toyota Way, Springer, Singapore.

Green, S. D., 1999. The Dark Side of Lean Construction: Exploitation and Ideology.
Proceedings IGLC-7, University of California, Berkeley.

Green, S. D., dan May, S. C., 2005. Lean Construction: Arenas of Enactment, Models of Diffusion and The meaning of Leanness, Building Research and Information.

Hadiman, H., Hatmoko, J. U., dan Kristiani, F., 2014. Evaluasi Waste pada Proyek Gedung di Wilayah Semarang, Jurnal Karya Teknik Sipil Vol.3 No. 4.

Koskela, L., dan Howell, G., August, 2002. The theory of project management - problem and opportunity, Dalam Paper to be presented at the PMI Research Conference, Working Paper, VTT Technical Research Centre of Findland and Lean Construction Institute, Espoo.

Larasati, D., dan Watanabe, T., 2009. Evaluation Study on Existing Condition of Indonesian Construction Industry, Journal of Japan Society of Civil Engineering (JSCE) - Construction Management; Vol. 16, p. 399-410.

Liker, J., 2004. The Toyota Way: 14 management principles from the world's greatest manufacturer, Mc Graw-Hill, New York.

Ogunbiyi, O., 2014. Implementation of the Lean Approach in Sustainable Construction: A Conceptual Framework, Preston.

Picchi, F. A., dan Granja, A. D., 2004. Construction Sites: Using Lean Principles to Seek Broader Implementations, Annual Confrence of the International Group of Lean Construction, Helsinger.

Soekiman, A., Pribadi, K., Soemardi, B., dan R.D., W., 2011. Factors Relating to Labor Productivity Affecting the Project Schedule Performance in Indonesia, The Twelfth East AsiaPacific Conference on Structural Engineering and Construction, Procedia Engineering 14 Elsevier.

Willar, D., 2012. Improving Quality Management System Implementation in Indonesian Construction Companies, Queensland University of Technology, Queensland.

Winch, G., 2006. Towards a theory of construction as production by projects, Building Research and Information, Vol. 34(2), 164-174.

Womack, J., dan Jones, D., 1996. Lean Thinking: Banish Waste and Create Wealth in Your Corporation, Simon \& Schuster, New York. 